\title{
ANALISIS KINERJA GURU SMK NEGERI 1 GEDONG TATAAN KABUPATEN PESAWARAN
}

\author{
Hazairin Habe \\ Fakultas Ekonomi Program Studi Manajemen, Universitas Sang Bumi Ruwa Jurai, Bandar Lampung
}

\section{ABSTRACT}

The problem in this study is whether motivation and Managerial Supervision affect teacher performance at SMK Negeri 1 Gedong Tataan Kabupaten Pesawaran. This study aims to determine the effect of motivation and Managerial Supervision on teacher performance. The hypothesis formulated is that there is an influence of motivation and managerial supervision on teacher performance both partially and simultaneously. The sample used in this study amounted to 95 teachers.

The results of partial hypothesis testing prove that motivation affects teacher performance, as well as managerial supervision has a positive effect on teacher performance. Hypothesis testing simultaneously motivation variables and managerial supervision variables have a positive effect on teacher performance. The results of the determination test show that simultaneously the teacher performance variables are able to be explained by motivation variables and Managerial Supervision of $85.3 \%$, the remaining $14.7 \%$ are other variables not examined.

Keywords: Motivation, Discipline, Performance

\section{PENDAHULUAN}

\subsection{Latar Belakang}

Dalam era desentralisasi seperti saat ini, di mana sektor pendidikan juga dikelola secara otonom oleh pemerintah daerah, dan praktis pendidikan harus ditingkatkan ke arah yang lebih baik dalam arti relevansinya bagi kepentingan daerah maupun kepentingan nasional. Manajemen sekolah saat ini memiliki kecenderungan ke arah school based management. Dalam konteks school based management, sekolah harus meningkatkan keikutsertaan masyarakat lokal dalam pengelolaannya untuk meningkatkan kualitas dan efisiensinya. Meskipun demikian otonomi pendidikan dalam konteks school based management harus dilakukan dengan selalu mengacu pada accountability (pertanggungjawaban kualitas) terhadap masyarakat, orangtua, siswa, maupun pemerintah pusat dan daerah.

Agar desentralisasi dan otonomi pendidikan berhasil dengan baik, kepemimpinan manajemen sekolah perlu diberdayakan. Pemberdayaan berarti peningkatan kemampuan secara fungsional sehingga manajemen sekolah mampu berperan sesuai dengan tugas, wewenang, dan tanggung jawabnya. Dengan proses dan program pemberdayaan, mereka akhirnya harus memiliki kinerja yang profesional dan fungsional. Manajemen sekolah harus bertindak sebagai sistem dan iklim yang efektif. Sebagai manajer yang baik, pimpinan sekolah harus mampu mengatur agar semua potensi sekolah dapat berfungsi secara optimal dalam mendukung tercapainya tujuan sekolah. Hal ini dapat dilakukan jika kepala sekolah mampu melakukan fungsi-fungsi manajemen dengan baik yang meliputi: (1) perencanaan; (2) pengorganisasian; (3) pengarahan; dan (4) pengawasan. Kemudian berdasarkan data dari obyek penelitian didapatkan bahwa hasil kerja tidak sejalan dengan apa yang dilakukan oleh guru dan dijelaskan dalam tabel bawah.

Berdasarkan tabel di bawah terlihat bahwa fluktuasi kehadiran guru cenderung menurun walau terlihat masih tinggi yang dapat diartikan guru kurang Supervisi Manajerialdalam melakukan kegiatan sekolah, selain itu jumlah rencana pendidikan dan pengajaran (RPP) yang dikumpulkan belum mencapai persentase yang diharapkan sekolah. Kemudian soal yang dianalisis cenderung sedikit dan terkesan guru kurang memperhatikan analisis soal. 
Tabel 1.

Kinerja Guru dalam Kriteria (6 Bulan Terakhir)

\begin{tabular}{lccc}
\hline Bulan & $\begin{array}{c}\text { RPP } \\
\text { dikumpulkan }\end{array}$ & $\begin{array}{c}\text { Kehadiran } \\
\text { Guru }\end{array}$ & $\begin{array}{c}\text { Analisis } \\
\text { Soal }\end{array}$ \\
\hline Maret & $78 \%$ & $72 \%$ & $48 \%$ \\
April & $79 \%$ & $80 \%$ & $42 \%$ \\
Mei & $75 \%$ & $79 \%$ & $42 \%$ \\
Juni & $65 \%$ & $75 \%$ & $35 \%$ \\
Juli & $73 \%$ & $80 \%$ & $43 \%$ \\
Agustus & $75 \%$ & $88 \%$ & $35 \%$ \\
Rata- & $74 \%$ & $79 \%$ & $41 \%$ \\
Rata & \multicolumn{3}{l}{} \\
Sumber : SMK Negeri 1 Gedong Tataan 2018
\end{tabular}

Agar proses inovasi di sekolah dapat berjalan dengan baik, kepala sekolah perlu dan harus bertindak sebagai pemimpin (leader), dan bukannya bertindak sebagai boss. Kepemimpinan kepala sekolah harus menghindari terciptanya pola hubungan dengan guru yang hanya mengandalkan kekuasaan. Sebaliknya perlu mengedepankan kerja sama fungsional; menghindarkan diri dari one man show, sebaliknya harus menekankan pada kerjasama kesejawatan; menghindari terciptanya suasana kerja yang serba menakutkan, sebaliknya perlu rnenciptakan keadaan yang membuat semua guru percaya diri; menghindarkan diri dari wacana retorika, sebaliknya perlu membuktikan memiliki kemampuan unjuk kerja profesional; menghindarkan diri dari sifat dengki dan kebencian, sebaliknya harus menumbuh kembangkan antusias kerja para guru; menghindarkan diri dari suka menyalahkan guru, tetapi harus mampu memperbaiki (mengoreksi) kesalahan guru; dan menghindarkan diri agar tidak menyebabkan pekerjaan guru menjadi membosankan, tetapi sebaliknya justru harus mampu membuat suasana kerja yang membuat guru tertarik dan betah melakukan pekerjaannya. Disamping dituntut untuk terus melakukan motivasi seorang kepala sekolah harus memperhatikan hal-hal yang berkaitan dengan kinerja guru.

Pembinaan oleh manajemen sekolah di lingkungan SMK Negeri 1 Gedong Tataan Kabupaten Pesawaran telah diatur dalam Undang-Undang, Peraturan Pemerintah maupun Peraturan Daerah dan pelaksanaannya, namun masih banyak ditemui hambatan yang menimbulkan masalah dengan berbagai pengaruhnya dalam rangka menerapkan prinsip-prinsip motivasi, guna meningkatkan prestasi kerja guru seperti Supervisi ManajerialGuru, dedikasi dan loyalitas.

\subsection{Perumusan Masalah}

1. Apakah motivasi berpengaruh terhadap kinerja guru di SMK Negeri 1 Gedong Tataan Kabupaten Pesawaran?

2. Apakah supervisi manajerial berpengaruh terhadap kinerja guru di SMK Negeri 1 Gedong Tataan Kabupaten Pesawaran?

3. Apakah motivasi dan supervisi manajerial berpengaruh terhadap kinerja guru di SMK Negeri 1 Gedong Tataan Kabupaten Pesawaran?

\subsection{Tujuan Penelitian}

1. Untuk mengukur sejauhmana pengaruh motivasi terhadap kinerja guru di SMK Negeri 1 Gedong Tataan Kabupaten Pesawaran.

2. Untuk mengukur sejauhmana pengaruh supervisi manajerial terhadap kinerja guru di SMK Negeri 1 Gedong Tataan Kabupaten Pesawaran.

3. Untuk mengukur sejauhmana pengaruh motivasi dan supervisi manajerial terhadap kinerja guru di SMK Negeri 1 Gedong Tataan Kabupaten Pesawaran.

\section{TINJAUAN PUSTAKA}

\subsection{Motivasi}

Pengertian Motivasi adalah serangkaian sikap dan nilai-nilai yang mempengaruhi individu untuk mencapai hal yang spesifik sesuai dengan tujuan individu. Sikap dan nilai tersebut merupakan suatu yang invisible (tidak terlihat) yang memberikan kekuatan untuk mendorong individu bertingkah laku dalam mencapai tujuan As'ad (2010). Dorongan tersebut terdiri dan 2 (dua) komponen, yaitu: arah perilaku (kerja untuk mencapai tujuan), dan kekuatan perilaku (seberapa kuat usaha individu dalam bekerja). Motivasi meliputi perasaan unik, pemikiranan dan pengalaman masa lalu yang merupakan 
bagian dari hubungan internal dan eksternal lembaga. Selain itu Motivasi Kerja dapat pula diartikan sebagai dorongan individu untuk melakukan tindakan karena mereka ingin melakukannya. Apabila individu termotivasi, mereka akan membuat pilihan yang positif untuk melakukan sesuatu, karena dapat memuaskan keinginan mereka. Bambang (2013)

\section{Teori Tiga Kebutuhan David Mc Clealland}

Menurut teori yang dikemukakan oleh David Mc Clelland, bahwa setiap orang (individu) mempunyai tiga kebutuhan pokok yang mendorong tingkah lakunya (Robbins; 2008: 228), yaitu : 1) Need For Archievenement merupakan kebutuhan untuk mencapai sukses (Keberhasilan) dalam hidupnya, termasuk dalam pekerjaannya. Dalam kehidupan organisasional, kebutuhan untuk mencapai sukses ini, tercermin adanya dorongan untuk meraih prestasi sesuai standar yang telah ditetapkan. 3) Need for Affiliation merupakan kebutuhan akan situasi persahabatan dan kehangatan dalam interaksi dengan orang lain dalam organisasi, baik orang itu merupakan teman sekerja, bawahan maupun atasannya. Kebutuhan akan afflikasi biasanya diusahakan agar terpenuhi melalui kerjasama dengan orang lain. 3) Need for Power merupakan kebutuhan untuk menguasai dan mempengaruhi orang lain. Kebutuhan ini menyebabkan orang yang bersangkutan tidak atau kurang mempedulikan perasaan orang lain.

Dalam penelitian ini konsep motivasi kerja menurut As'ad (2010)diartikan sebagai "Serangkaian sikap dan nilai-nilai yang mempengaruhi individu untuk mencapai hal yang spesifik sesuai dengan tujuan individu. Sikap dan nilai tersebut merupakan suatu yang invisible yang memberikan kekuatan untuk mendorong individu bertingkah laku dalam mencapai tujuan. Dengan indikator pengukuran konsep adalah sebagai berikut Schermerhorn (2009) : Teori kebutuhan dasar guru, Teori pendekatan yang mendukung proses,Teori resiko masa lalu dan masa mendatang

\subsection{Supervisi Manajerial}

Kata Supervisi dapat didefinisikan secara etimologis yang berasal dari bahasa Inggris Supervision. Supervisi berarti di atas, sedangkan vision berarti penglihatan/melihat. Jika diartikan bebas, maka supervision dapat pula dimaknai melihat dari atas. Arti kata supervisi in tidak bisa dimaknai secara harafiah sebagai kegiatan melihat orang lain dari atas, namun lebih kepada makna mengawasi orang lain yang dilakukan oleh orang yang memiliki jabatan tinggi ke orang yang memiliki jabatan lebih rendah. Supervisi adalah kegiatan yang ditujukan untuk memperbaiki proses dan prestasi pendidikan. Atau bantuan yang diberikan kepada guru dan seluruh staf untuk mengembangkan situasi pembelajaran yang lebih baik.

Menurut Mulyasa (2006), Supervisi sesungguhnya dapat dilaksanakan oleh kepala sekolah yang berperan sebagai supervisor, tetapi dalam sistem organisasi modern diperlukan supervisor khusus yang lebih independent dan dapat meningkatkan obyektifitas dalam pembinaan dan pelaksanaan tugas. Dalam Panduan Pelaksanaan Tugas Pengawas Sekolah/Madrasah (Direktorat Tenaga Kependidikan, 2009:20) dinyatakan bahwa Supervisi Manajerial adalah supervisi yang berkenaan dengan aspek pengelolaan sekolah yang terkait langsung dengan peningkatan efisiensi dan efektivitas sekolah yang mencakup perencanaan, koordinasi, pelaksanaan, penilaian, pengembangan kompetensi sumberdaya manusia (SDM) kependidikan dan sumber daya lainnya.

Berdasarkan Panduan Pelaksanaan Tugas Pengawas Sekolah/Madrasah (Direktorat Tenaga Kependidikan, 2009:20), dalam melaksanakan fungsi supervisi manajerial, pengawas sekolah/madrasah berperan sebagai : (1) kolaborator dan negosiator dalam proses perencanaan, koordinasi, pengembangan manajemen sekolah; (2) asesor dalam mengidentifikasi kelemahan dan menganalisis potensi sekolah; (3) pusat informasi pengembangan mutu sekolah; (4) evaluator terhadap pemaknaan hasil pengawasan. 
Menurut Panduan Pelaksanaan Tugas

Pengawas Sekolah/Madrasah (Direktorat Tenaga Kependidikan, 2009:20), dalam pelaksanaan supervisi manajerial, pengawas dapat menerapkan teknik supervisi individual dan kelompok. Teknik supervisi individual adalah pelaksanaan supervisi yang diberikan kepada kepala sekolah atau personil lainnya yang mempunyai masalah khusus dan bersifat perorangan. Teknik supervisi kelompok adalah salah satu cara melaksanakan program supervisi yang ditujukan pada dua orang atau lebih. Metode Teknik Supervisi Manajerial menurut (Rochiat, 2008 : 115) yaitu:

1. Monitoring dan Evaluasi. Monitoring adalah kegiatan yang ditujukan untuk mengetahui perkembangan pelaksanaan penyelengaraan sekolah, apakah sesuai program atau standar yang telah ditetapkan. Evaluasi yaitu kegiatan untuk mengetahui sejauhmana kesuksesan/keberhasilan penyelenggaraan sekolah yang telah dicapai dalam kurun waktu.

2. Refleksi dan Focused Group Discussion. Secara bersama-sama pihak sekolah melakukan refleksi terhadap data yang ada dan menemukan faktor penghambat serta pendukung yang selama ini mereka rasakan.

3. Metode Delphi. Dengan metode ini didapatkan cara yang efisien untuk melibatkan stakeholder sekolah tanpa memandang faktor-faktor status yang sering menjadi kendala sebuah diskusi/musyawarah.

\subsection{Kinerja Guru}

Ruky (2012) Penilaian kinerja terjemahan dari performance appraisal. Tetapi karena banyak organisasi menghindari kata appraisal (penilaian) dengan berbagai alasan atau pertimbangan, maka dipakai juga istilah : staff development, performance review, development needs assessment untuk mengganti istilah penilaian kinerja. Menurut Hasibuan (2010: 87) pengertian penilaian kinerja adalah kegiatan manajer untuk mengevaluasi perilaku kinerja kerja guru serta menetapkan kebijaksanaan selanjutnya, dan penilaian kinerja kerja adalah menilai hasil kerja nyata dengan standar kualitas maupun kuantitas yng dihasilkan oleh setiap guru.

Bernardin dan Russel (Kreitner: 2013: 96) mendefinisikan penilaian kinerja sebagai "...a way of measuring the contributions of individuals to their organization..". atau suatu cara untuk mengukur berbagai kontribusi yang diberikan oleh setiap individu bagi organisasinya. Kinerja (performance) sendiri oleh Bernardin dan Russel (Kreitner: 2013: 94) didefinisikan sebagai "..the record of outcomes produced on a specified job function or activity during a specify field time periods" (riwayat pekerjaan pada penciptaan hasil pada sebuah fungsi kerja yang khusus atau aktivitas selama sebuah spesifikasi periode waktu).

Dalam penelitian ini konsep kinerja menurut Kreitner (2013) didefinisikan sebagai Kegiatan evaluasi terhadap kesetiaan, motivasi, disiplin, kerjasama, loyalitas, dedikasi, dan partisipasi sebagai kontribusi keseluruhan yang diberikan oleh setiap individu bagi organisasinya. Dengan indikator pengukuran konsep yang akan digunakan dalam penelitian ini adalah sebagai berikut (Mathis; 2006; 378): Kuantitas dari hasil, Kualitas dari hasil, Ketepatan waktu dari hasil, Kehadiran, Komunikasi bekerja sama. 


\subsection{Konsep Penelitian Hipotesis}

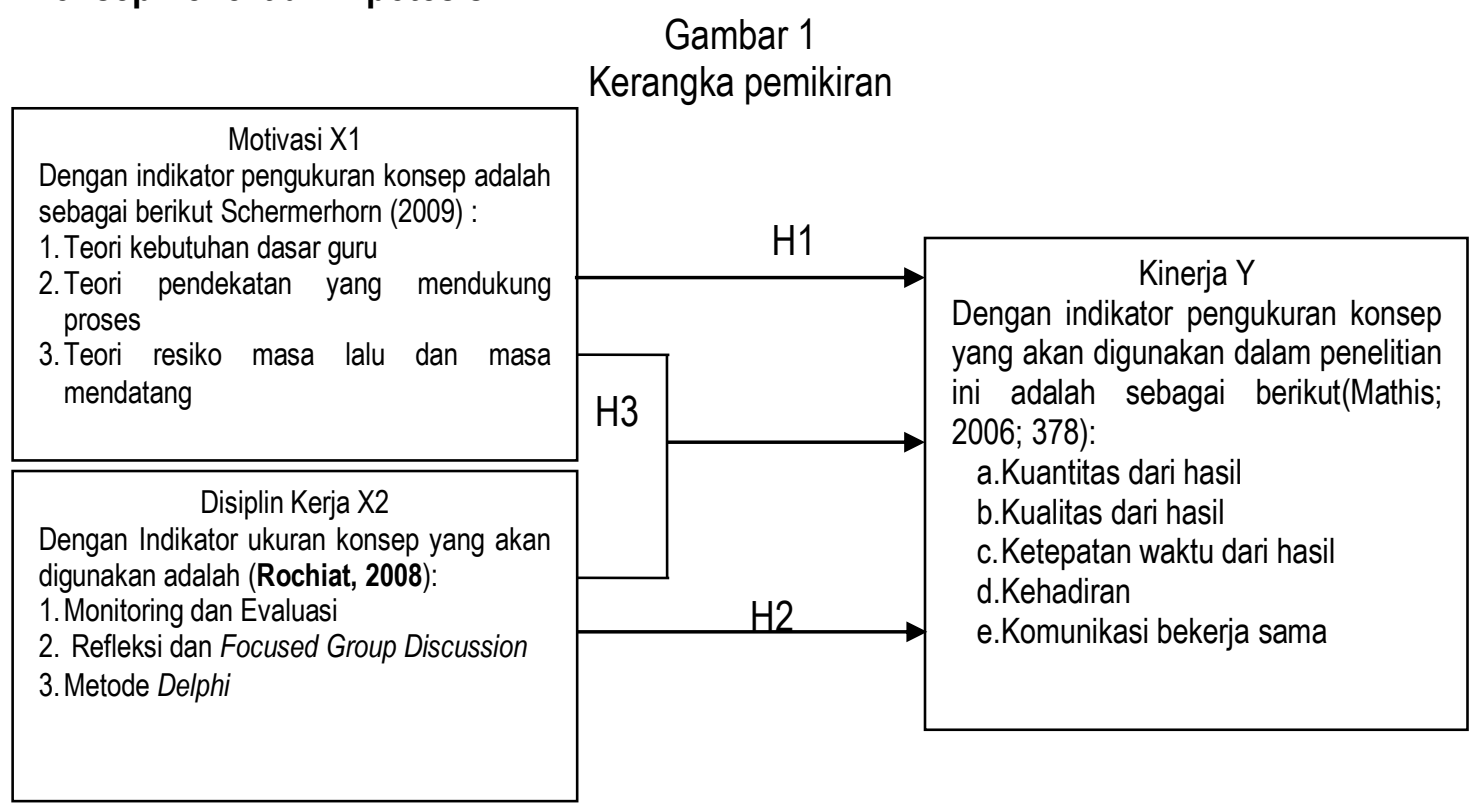

1. Diduga motivasi kerja berpengaruh terhadap kinerja guru SMK Negeri 1 Gedong Tataan Kabupaten Pesawaran.

2. Diduga supervisi manajerial berpengaruh terhadap kinerja guru SMA Negeri 1 Gedong Tataan Kabupaten Pesawaran.

3. Diduga motivasi dan supervisi manajerial berpengaruh terhadap kinerja guru SMK Negeri 1 Gedong Tataan Kabupaten Pesawaran

\section{METODOLOGI PENELITIAN}

\subsection{Jenis Penelitian}

Pemilihan dan penggunaan desain survei dengan metode analitik korelasional dalam penelitian ini, untuk mengukur dan analisis sejauh mana atau seberapa besar pengaruh motivasi dan supervisi manajerial terhadap kinerja guru SMK Negeri 1 Gedong Tataan Kabupaten Pesawaran.

\subsection{Populasi dan Sampel}

Menurut Arikunto (2012 : 13), unit analisis adalah satuan tertentu yang diperhitungkan sebagai subyek penelitian, dengan demikian, unit analisis dalam penelitian ini adalah keseluruhan Guru SMK Negeri 1 Gedong Tataan Kabupaten Pesawaran. Menurut Sugiono, (2010) Populasi adalah jumlah keseluruhan dari unit analisis yang bagiannya akan digunakan dalam penelitian. Dengan demikian Populasi dalam penelitian ini adalah keseluruhan Guru SMK Negeri 1 Gedong Tataan Kabupaten Pesawaran beserta perangkatnya, yang secara terinci dapat terdiri atas tenaga kependidikan $=70$ orang, guru honorer $=25$ orang sehingga total populasi $=$ 95 orang. Populasi adalah wilayah generalisasi yang terdiri atas; obyek atau subyek yang mempuyai kuantitas dan karakteristik tertentu yang ditetapkan oleh peneliti untuk dipelajari dan kemudian ditarik kesimpulannya. Jumlah populasi Guru SMK Negeri 1 Gedong Tataan Kabupaten Pesawaran adalah 95 orang. Metode penarikan sample dengan menggunakan metode sampling jenuh (Sekaran 2010).

\subsection{Teknik Pengumpulan Data}

Data yang diperlukan dalam penelitian ini meliputi data primer yakni data yang diperoleh langsung melalui penelitian, baik melalui penggunaan kuesioner maupun wawancara. Sedangkan data skunder, data yang diperoleh dari teknik dokumentasi dengan memanfaatkan sumber-sumber yang berkaitan dan dapat mendukung obyek yang akan diteliti.

\subsection{Teknik Analisa Data}

Dalam Penelitian ini metode analisis yang digunakan adalah sebagai berikut: 
1. Uji Validitas, kuesioner dikatakan valid jika pertanyaan pada kuesioner mampu mengungkapkan sesuatu yang akan diukur oleh kuesioner tersebut. Rumus yang dipakai adalah (Djamaluddin, dalam Haryono, (2007)):

$$
\begin{aligned}
& \mathrm{r}=\frac{n \sum x y-\left(\sum x\right)\left(\sum y\right)}{\sqrt{\left[n \sum x^{2}-\left(\sum x\right)\right]^{2}\left[n \sum y^{2}-\left(\sum y\right)\right]^{2}}} \\
& \mathrm{rn}=\begin{array}{l}
\text { Koefisien korelasi antara item } \\
\text { dengan total skor }
\end{array} \\
& \sum \mathrm{x}=\begin{array}{l}
\text { Skor pertanyaan yang } \\
\text { dihitung validitasnya }
\end{array} \\
& \sum \mathrm{y}=\begin{array}{l}
\text { Jumlah skor untuk variabel } \\
\text { yang terdiri dari beberapa } \\
\text { komponen pertanyaan }
\end{array} \\
& \mathrm{N}=\begin{array}{l}
\text { Jumlah sampel } \\
\mathrm{N}
\end{array}
\end{aligned}
$$

2. Uji Reliabilitas, menunjukkan konsistensi dan stabilitas dari skala pengukuran, reliabilitas lebih berpusat pada stabilitas yang mengacu pada sejauh mana pengukuran yang dilakukan bebas dari kesalahan dan memberi hasil yang relatif sama atau tidak jauh berbeda bila dilakukan pengukuran yang berbeda walaupun dengan subyek yang sama Haryono, (2007). Selanjutnya dilakukan optimasi keseluruhan test dengan menggunakan koefisien alpha yang dikemukakan Gronbach dengan rumus:

$$
\begin{aligned}
& \alpha=\left[\frac{J}{J-1}\right]\left[\frac{S^{2} X \ldots \ldots \ldots . . \sum S^{2} Y J}{S^{2}}\right] \\
& S^{2} \mathrm{X}=\begin{array}{l}
\text { Varian skor subyek pada } \\
\text { keseluruhan test yang terdiri } \\
\text { dari beberapa pernyataan }
\end{array} \\
& \mathrm{S}^{2} \mathrm{YJ}=\begin{array}{l}
\text { Varian skor subyek pada } \\
\text { belahan ke-J dimana } \mathrm{J}= \\
1,2,3, \ldots . . \mathrm{J}
\end{array} \\
& \alpha \quad=\text { Koefisien reliabilitas alpha }
\end{aligned}
$$

Nilai Koefisien alpha harus setinggi mungkin atau sekitar 0,6 Haryono, (2007)
3. Analisis Statistik, menurut Arikunto (2012) adalah yang digunakan seluruh rangkaian kerja suatu penelitian, diantaranya merumuskan hipotesis, menyusun instrumen peneltian, menentukan sampel, menganalisis data dan terahir menarik suatu kesimpulan dari suatu penelitian. Berdasarkan hipotesis yang diajukan dalam penelitian ini, untuk mengetahui bentuk hubungan pengaruh antara variabel bebas $(X)$ terhadap variabel terikat $(\mathrm{Y})$ digunakan analisis statistik.

Dalam hal ini $r$ YX merupakan koefisien korelasi pearson untuk uji validitas dan alpha pada reliabilitas. Struktur hubungan variabel tersebut dapat dinyatakan ke dalam persamaan regresi, yaitu : $Y=b_{0}+b_{1} x_{1}+b_{2} X_{2}$

Menurut Arikunto (2012) untuk memeriksa apakah hubungan pengaruh antara variabel $X$ dan $Y$ yang kedua-duanya pangkat ukuran ordinal digunakan korelasi Rank Spearman ( Spearman's Coefficient of Rank Correlation ). berikut :

Perumusan matematisnya sebagai

rs

$$
\begin{aligned}
& =\frac{\sum R(X) R(Y)-n \frac{(\mathrm{n}+1)}{2} x^{2}}{\left.\sqrt{\left[\sum R(X)^{2}\right.}-n\left(\frac{n+1}{2}\right)\right]\left[\sum R(Y)^{2}-n\left(\frac{n+1}{2}\right)\right.} \frac{1}{2} \\
& \text { Keterangan : } \\
& \mathrm{Rs}=\text { Koefisien korelasi Rank spearman } \\
& \mathrm{R}(\mathrm{Xi})=\text { ranking dar variabel X } \\
& \mathrm{R}(\mathrm{Yi})=\text { ranking dari variabel } \\
& \mathrm{n} \quad=\text { jumlah sampel }
\end{aligned}
$$

Untuk mengetahui apakah hubungan dan variabel tersebut betul-betul bermakna atau hanya terjadi secara kebetulan, perlu dilakukan uji signifikansi dengan menggunakan rumus uji t, yaitu Arikunto (2012):

$$
\mathrm{t}-\mathrm{h}=r s \sqrt{\frac{n-2}{1-r \frac{2}{s}}}
$$


Hasil perhitungan test signifikan ini, kemudian dikonsoltasikan dengan nilai kritik $t$ pada tabel distribusi stdent $t$, df.n-2 pada tingkat signifikansi untuk test dua sisi $\alpha=0,05$. Bila nilai $t$ hitung lebih besar dari pada nilai $t$ tabel ( $\mathrm{t}-\mathrm{h}>\mathrm{t}-\mathrm{t}$ ), maka hubungan antara dua variabel adalah sgnifikan. Sedangkan bila nilai $t$ hitung lebih kecil kecil dari nilai $t$ tabel $(\mathrm{t}-\mathrm{h}<\mathrm{t}-\mathrm{t}$ ), maka hubungan tersebut tidfak signifikan, atau hubungan terjadi karena kebetulan saja.

\section{HASIL PENELITIAN DAN PEMBAHASAN}

\subsection{Analisis Instrumen Penelitian}

Berdasarkan hasil pengujian indeks menunjukan validitas (corrected item-total correlation) koefisien korelasi item pada variabel seluruhnya valid. Sehingga pada uji reliabilitas tidak semua item pernyataan variabel dilakukan uji karena hanya butir yang valid saja yang digunakan. Hasil analisis uji reliabilitas yang terjadi menunjukkan bahwa kuesioner reliable, karena skor alpha positif dengan nilai lebih besar dari 0.6 Arikunto (2012). Dengan demikian dapat dikatakan kuesioner variabel $Y$ layak untuk digunakan dalam pengambilan data penelitian.

\subsection{Analisis Data Penelitian}

Dalam penelitian ini responden berjumlah 95 responden yang merupakan sampel jenuh dan datanya digunakan untuk dianalisis. Sebelum dilakukan pengolahan data regresi berganda perlu dilakukan uji terhadap asumsi klasik untuk menghindari asumsi klasik yaitu uji normalitas, dan uji homogenitas.

1. Uji Normalitas, berdasarkan hasil uji, pola penyebaran yang terjadi berada pada sekitar garis diagonal dan mengikuti garis diagonal dan masih disekitaran sumbu normal. Ini berarti bahwa model regresi dalam penelitian ini sudah memenuhi asumsi normalitas.

2. Uji Homogenitas, Berdasarkan hasil uji, diketahui bahwa penyebaran nilai - nilai perbandingan tersebut tidak membentuk pola tertentu sehingga keadaan homogenitas dapat terpenuhi pada homogenitas variabel $\mathrm{X}_{2} \quad$ (supervisi manajerial) dan variabel $Y$ (kinerja).

3. Uji Regresi Berganda

Setelah uji Normalitas dan Homogenitas terpenuhi maka data siap untuk dilakukan uji regresi berganda guna pembuktian hipotesis penelitian. Guna memudahkan interpretasi dari hasil regresi linier berganda maka hasil analisis dirangkum dalam gambar rangkuman hasil uji yang ditampilkan sebagai berikut:

Gambar 2

Rangkuman Hasil Analisis Penelitian

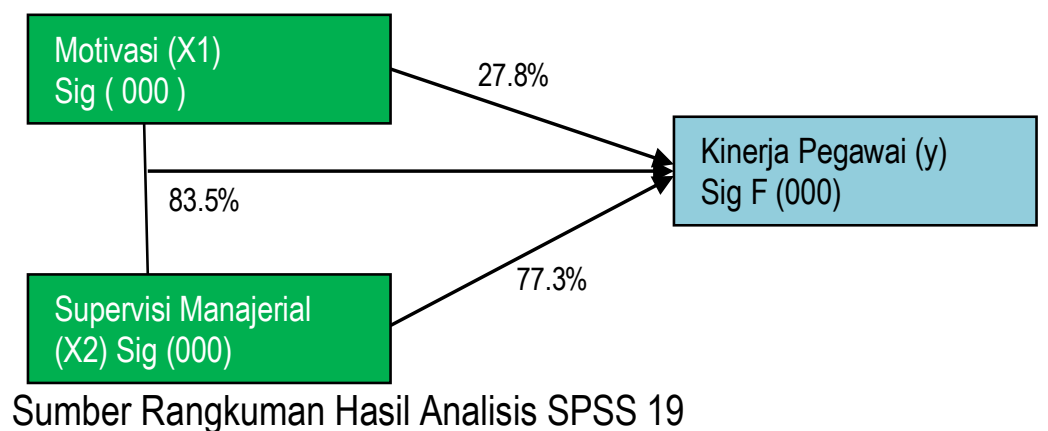

Pembahasan dari hasil rangkuman analisis tersebut maka gambar tersebut dapat diinterpretasikan bahwa motivasi dan supervisi manajerial memiliki pengaruh yang besar terhadap kinerja guru di SMK Negeri 1 Gedong
Tataan Kabupaten Pesawaran dengan variabel supervisi manajerial sebagai variabel dominan yang mempengaruhi kinerja guru di SMK Negeri 1 Gedong Tataan Kabupaten Pesawaran. Pada variabel Motivasi juga 
didapatkan bahwa butir 5 yaitu Anda selalu menepati waktu penyelesaian pekerjaan memiliki rata-rata yang paling kecil. Pada variabel supervisi manajerial butir 3 yang paling kecil rata - ratanya adalah Anda selalu berusaha mentaati peraturan. Kemudian Pada variabel kinerja guru butir yang paling kecil rata-ratanya adalah butir 8 yaitu Anda menghargai perbedaan dalam sekolah anda. Dari pengolahan data juga didapatkan bahwa masih ada variabel lain yang belum dimasukkan dan memiliki pengaruh pada kinerja guru di SMK Negeri 1 Gedong Tataan Kabupaten Pesawaran disebabkan adanya faktor di luar model yang ikut mempengaruhi kinerja guru di SMK Negeri 1 Gedong Tataan Kabupaten Pesawaran disamping variabel motivasi kerja dan supervisi manajerial.

\section{SIMPULAN DAN SARAN}

\subsection{Simpulan}

Motivasi berpengaruh terhadap kinerja guru di SMK Negeri 1 Gedong Tataan Kabupaten Pesawaran sebesar 27,8\% (persen) dan signifikan. Supervisi manajerial berpengaruh terhadap kinerja Guru di SMK Negeri 1 Gedong Tataan Kabupaten Pesawaran sebesar $77,3 \%$ (persen) dan signifikan. Motivasi dan supervisi manajerial berpengaruh terhadap kinerja guru di SMK Negeri 1 Gedong Tataan Kabupaten Pesawaran sebesar 40,8\% (persen). Sedangkan $85.3 \%$ (persen) sisanya adalah pengaruh dari variabel atau faktor-faktor lain diluar model.

\subsection{Saran}

Hasil penelitian yang dilakukan memiliki interpretasi bahwa masih ada faktor diluar model yang ikut mempengaruhi Kinerja Guru maka saran yang dapat diberikan adalah memasukkan variabel lain dalam model yang diduga memiliki pengaruh juga seperti kompensasi, gaya kepemimpinan, budaya organisasi, sistem informasi manajemen, sarana, prasarana dan kompetensi.

Secara praktis manfaat yang dapat dihasilkan dalam penelitian ini adalah pada variabel motivasi diharapkan SMK Negeri 1 Gedong Tataan Kabupaten Pesawaran melakukan perbaikkan pada guru selalu menepati waktu penyelesaian pekerjaan dengan cara melakukan pengkajian pekerjaan disebabkan memiliki rata-rata butir yang paling kecil sehingga berpotensi dapat menurunkan motivasi. Pada Variabel supervisi manajerial disarankan untuk memperbaiki perilaku dan kebiasaan buruk guru dalam usaha mentaati peraturan dari pekerjaan dengan melakukan penindakan akibat perbuatan melanggar para guru dengan tegas. Kemudian variabel kinerja guru sebagai variabel terikat dalam penelitian ini adalah dengan memperbaiki pada proses menghargai perbedaan dalam pendapat dan pandangan dalam sekolah SMK Negeri 1 Gedong Tataan Kabupaten Pesawaran sebagai suatu hal yang wajar dalam organisasi.

\section{DAFTAR PUSTAKA}

Abin Syamsuddin Makmun. 2013. Psikologi Pendidikan; Bandung. PT. Remaja. Rosda Karya.

Ahmadi, A dan S. Widodo. 2012. Psikologi Belajar. Jakarta : Rineka Cipta

Arikunto, Suharsimi. 2012. Prosedur penelitian suatu Pendekatan Praktik. Rineka Citra, Jakarta.

As'ad, Moh. 2010, Psikologi Industri, Yogyakarta, Liberty.

Davis Keith, New Strom, Jhon W. 2012, Perilaku Dalam Organisasi, Jilid I, Alih bahasa Sutopo, Jakarta, Erlangga.

Hasibuan, S. P. Malayu. 2010, Manajemen Sumber Daya Manusia Dasar dan Kunci Keberhasilan. Jakarta : PT. Toko Gunung Agung.

Handoko Hani T. 2011, Manajemen Personalia dan Sumber Daya Manusia, Yogyakarta, BPFE.

Jacob, Gareth R, 2010, Organizational Theory, Text and Cases, Third Edition, Boston, Prentice Hall.

Kreitner \& Kinichi, 2013, Organizational Behavior, Needham Heights, USA :Allyn And Bacon,.

Mangkunegara Anwar Prabu A. A. 2011, Manajemen Sumber Daya Manusia Perusahaan, Bandung : PT. Remaja Rosdakarya. 
Milkovich, G.J \& Bourddreau, J.W. 2009 Human Resource Management. Eighth Edition, London, Richard D. Irwin, a Times Mirrom Higher Education Group. Inc, Company.

Mulyasa. 2003. Standar Kompetensi dan Sertifikasi Guru. Bandung : PT. Remaja Rosdakarya.

Ruky, Achmad S., 2012, Sistem Manajemen Kinerja, Jakarta, PT. Gramedia Pustaka Utama.

Sedarmayanti, 2007, Manajemen Sumber Daya Manusia, Bandung, Refika Aditama

Siagian Sondang P., 2012. Kiat Meningkatkan Produktivitas Kerja, Cetakan Pertama, , Jakarta: PT. Rineka Cipta.

Sugiono, 2010 Metode Penelitian Pendidikan, Penerbit Alfabeta, Bandung. 2010.

Sekaran Uma. 2010, Research Methods For Business, New York :John Wiley \& Sons, Inc.

Su'ad, Husnan dan Heidjrachman, 2012, Penilaian Kinerja dan Pengembangan Karyawan, Yogyakarta, BPFE. 
ISSN 2086-9592 